\section{AMERICAN ECOLOGY, 1968}

\section{Challenge for Survival}

Land, Air and Water for Man in Megalopolis. Edited by Pierre Dansereau, with the assistance of Virginia Weadock. Pp. xii + 235. (Columbia University Press: New York and London, April 1970.) $72 s ; \$ 7.95$.

Books composed from the papers and discussions of conferences carry built-in handicaps, which only the best of them manage to surmount. This one results from a symposium in April 1968 organized by that distinguished and far-sceing ecologist Pierre Dansereau, at that time senior curator in ecology at the New York Botanical Garden which presented the project with the backing of the National Science Foundation.

It is interesting in European Conservation Year to have this further testimony to the convergence of advanced thinking on ecology applied to the total environment in North America with the lines which have been simultaneously developed on the European side of the Atlantic. The style, both in a wider and a strict sense, is refreshingly different, but the material reviewed and the conclusions reached are parallel and similar even where they are not identical. Dansereau's own scholarly essay goes well boyond its titlo "Megalopolis: Resources and Prospect". Other contrlbutions, such as Frank E. Egler's "Ecology and Management of the Rural and the Suburban Landscape", follow the line of blending a provocative essay-type review with a somewhat sketchy presentation of fact and a number of practical criticisms and proposals.

Helmut E. Landsberg's "Metropolitan Air Layers and Pollution", George M. Woodwell's "Radioactivity and Fallout: the Model Pollution", and David M. Gates's "Relationship between Plants and Atmosphere", help to provide a slightly more solid raft. Soveral of the papers have already appeared elsewhere in slightly different form. References to literature are on the light side and there is no index.

Challenge for Survival is to be recommended therefore simply as a stimulating series of loosely connected essays by a group of loading American ecologists and others who have something constructive and coherent, to say on the present state of ecology and its immense implications for public affairs. Although, as one of the contributors says, we may in a sense have heard it all before, this is one of the best and most succinct statements, in spite of its obvious unevenness, and it will help as a corrective on some of the aspects which European work tends to neglect.

Americans are good at this sort of thing but, as several of the writers remind us, ecology in the United States has been very backward in rising to its social responsibilities. To a European, however, it is somewhat baffling to see so little result in practice to show for so much lively and persuasive illumination as the American record incessantly adds to itself.

E. M. NICHOLSON

\section{FISH DISEASES}

Principal Diseases of Marine Fish and Shellfish

By Carl J. Sindermann. Pp. $\mathrm{x}+369$. (Academic Press: London and New York, April 1970.) $163 s$.

INFORMATION about diseases in marine animals is widely distributed through the world literature. Dr Sindermann's book provides an excellent summary of existing knowledge. It is an expansion of two earlier reviews ${ }^{1,2}$.

The introduction forms the first chapter. Nine hypotheses are given about the role of diseases in the marine environment. Chapter two gives an account of the diseases of marine fishes. A short preliminary section indicates how access to the literaturo is achieved, followed by sections on microbial diseases, including viruses, bacteria, fungi and Protozoa, discases caused by helminths and parasitic Crustacea, and, finally, genetic and environmentally induced abnormalities. 'The diseases of commercially valuable food fishes are emphasized throughout. Each section is divided into appropriate subsections giving a concise account of the range of diseases. A complete review is not attempted; enough information is provided to enable the reader to appreciate the problems involved and to gain entry to the original literature. Drawings of photographs illustrate representative disease symptoms of organisms. Twenty-soven pages of references conchude the chapter.

The same style is followed in the third chapter on the. diseases of shellfish. Mollusca and Crustacea are treated separately. The mollusc section is divided into bivalves, gastropods and cephalopods. The section on bivalves is the most extensive: oysters, mussels, clams, scallops and pearl oysters each get individual consideration. Because of the use of these narrower topics, the account is more comprehensive than that given in the chapter on fish diseases. The Crustacea are divided into three subdivisions, crabs, lobsters and shrimps. Fewer illustrations are provided than in the previous chapter. There are twenty-one pages of references for molluses and eleven for crustaceans.

A basic review of the range of disease organisms is thus provided in chapters two and three. The treatment is thorough, but not exhaustive. It is not intended to provide a means of identification of disease symptoms or organisms, but it does provide a good introduction to the areas of study.

The remaining chapters deal with six topics of importance in relation to disease in the marine environment. For many readers they will be the most interesting part of the book. The following topies are considered: mortalities of marine animals, with emphasis on the role of disease in North American clupeoid fishes and shellfish, disease and parasite problems in marine aquaria and cultivated marine populations, vertebrate and invertebrate defence mechanisms, the relationship of human diseases to diseases of marine animals, and an assessment of the role of disease in the marine enviromment. Finally, there is a brief discussion of problems of future studies of diseases in the marine environment. References are given at the end of all chapters. 'There are author and subject indexes.

\section{Jayrs C. ChüB}

${ }^{1}$ Sindermann, C. J., Adr. Mar. Biol., 4, 1 (1966).

2 Sinderman, C. J., and Rosenfield, A., Fishery Bull. L $^{r}$ S Fish Wild. Sere. 66, 335 (1967).

\section{PROTECTORS AND SENSITIZERS}

\section{Radiation Protection and Sensitization}

Edited by Harold Moroson and Marcello Quintiliani. (Pro. ceedings of the Socond International Symposium of Radio. sensitizing and Radioprotective Drugs, Rome, May 1969. Pp. xvi +522 . ('Taylor and Francis: London, March 1970.) $160 s$.

THe design of this symposium was good; a discussion of both radiation protection and sensitization together at difforent levels of organization. Unfortunately, no account of the discussion after the various papers appears in the published proceedings, which consist of five review articles and sixty-eight shorter contributions, some of which are good and some of which are slight.

It is clear that while work on molecular and single cell systems is devoted more to sensitization than to protection, the emphasis in multicellular studies is still on protection. Adams reviews some model radiation chomical and collular systems in a clear and casily read account, dealing generally with both mechanisms, as does Alexander and his colleaguos' review of DNA repair in two different cell systems, mouse lymphoma and Micrococcus radiodurans. The section on single cell systems contains a good account from Block, Mulligan, Weidner and Doherty of change from protectivo to sensitizing effects with substitution in a series of ehelat- 